\title{
Divergent Response Profile in Activated Cord Blood T cells from First-born Child Implies Birth-order-associated in Utero Immune Programming
}

Kragh, Marie; Larsen, Jeppe Madura; Thysen, Anna Hammerich; Rasmussen, Morten Arendt; Wolsk, Helene Mygind; Bisgaard, Hans Flinker; Pedersen, Susanne Brix

\section{Published in:}

Allergy

Link to article, DOI:

10.1111/all.12799

Publication date:

2016

Document Version

Peer reviewed version

Link back to DTU Orbit

Citation (APA):

Kragh, M., Larsen, J. M., Thysen, A. H., Rasmussen, M. A., Wolsk, H. M., Bisgaard, H. F., \& Pedersen, S. B. (2016). Divergent Response Profile in Activated Cord Blood T cells from First-born Child Implies Birth-orderassociated in Utero Immune Programming. Allergy, 71(3). https://doi.org/10.1111/all.12799

\section{General rights}

Copyright and moral rights for the publications made accessible in the public portal are retained by the authors and/or other copyright owners and it is a condition of accessing publications that users recognise and abide by the legal requirements associated with these rights.

- Users may download and print one copy of any publication from the public portal for the purpose of private study or research.

- You may not further distribute the material or use it for any profit-making activity or commercial gain

- You may freely distribute the URL identifying the publication in the public portal 
1 Divergent Response Profile in Activated Cord Blood T cells from First-born Child

\section{Implies Birth-order-associated in Utero Immune Programming}

Marie Kragh, MSc, PhD ${ }^{\mathrm{a}}$ Jeppe Madura Larsen, MSc, PhD, ${ }^{\mathrm{a}}$ Anna Hammerich Thysen, MSc, PhD, ${ }^{\mathrm{b}}$ Morten Arendt Rasmussen, MSc, PhD, ${ }^{\mathrm{b}}$ Helene Mygind Wolsk, MD, ${ }^{\mathrm{b}}$ Hans Bisgaard, $\mathrm{MD}, \mathrm{DMSc}^{\mathrm{b}}$ and Susanne Brix, MSc, $\mathrm{PhD}^{\mathrm{a},{ }^{*}}$.

${ }^{\mathrm{a} C e n t e r ~ f o r ~ B i o l o g i c a l ~ S e q u e n c e ~ A n a l y s i s, ~ D e p a r t m e n t ~ o f ~ S y s t e m s ~ B i o l o g y, ~ T e c h n i c a l ~}$ University of Denmark, Lyngby, Denmark.

${ }^{\mathrm{b}}$ Copenhagen Prospective Studies on Asthma in Childhood, Faculty of Health and Medical Sciences, University of Copenhagen \& Danish Pediatric Asthma Center, Gentofte Hospital, University of Copenhagen; Denmark.

\section{*Corresponding Author:}

Associate Professor Susanne Brix, Center for Biological Sequence Analysis, Department of Systems Biology, Technical University of Denmark, Søltofts Plads, 2800 Kgs. Lyngby, Denmark. Tel: (+45) 45252784, E-mail: sbp@bio.dtu.dk, Website: www.bio.dtu.dk

Fundings: COPSAC is funded by private and public research funds all listed on www.copsac.com. The Lundbeck Foundation; Danish State Budget; Danish Council for Strategic Research; The Danish Council for Independent Research and The Capital Region Research Foundation has provided core support for COPSAC. The funding agencies did not have any influence on study design, data collection and analysis, decision to publish or preparation of the manuscript. No pharmaceutical company was involved in the study. The funding agencies did not have any role in design and conduct of the study; collection, 
management, and interpretation of the data; or preparation, review, or approval of the manuscript. 


\section{ABSTRACT}

Background: First-born children are at higher risk for development of a range of immunemediated diseases. The underlying mechanism of 'birth-order-effects' on disease risk is largely unknown, but in utero programming of the child's immune system may play a role.

Objective: We studied the association between birth-order and the functional response of stimulated cord blood T cells.

Method: Purified cord blood T cells were polyclonally activated with anti-CD3/CD28coated beads in a subgroup of 28 children enrolled in the COPSAC 2010 birth cohort. Expression levels of seven activation markers on helper and cytotoxic T cells as well as the percentage of $\mathrm{CD} 4^{+} \mathrm{CD} 25^{+}$T cells were assessed by flow cytometry. Production of IFN- $\gamma$, TNF- $\alpha$, IL-17, IL-4, IL-5, IL-13 and IL-10 was measured in supernatants.

Results: IL-10 secretion $(\mathrm{P}=0.007)$ and CD25 expression on $\mathrm{CD} 4^{+}$helper $\mathrm{T}$ cells $(\mathrm{P}=$ 0.0003) in activated cord blood T cells were selectively reduced in first-born children, while the percentage of $\mathrm{CD} 4^{+} \mathrm{CD} 25^{+}$cord blood $\mathrm{T}$ cells was independent of birth-order.

Conclusion: First-born infants display a reduced anti-inflammatory profile in T cells at birth. This possible in utero 'birth-order' T cell programing may contribute to later development of immune-mediated diseases by increasing overall immune reactivity in firstborn children as compared to younger siblings. 


\section{Clinical Implications or Key Messages}

The prenatal period of life is a developmental window in which the fetal $\mathrm{T}$ cell immune response seems to be programmed by maternal parity status.

\section{Capsule Summary}

The authors report a reduced anti-inflammatory bias in the T cell function of first-born child.

This in utero programming of immunosuppressive mechanisms could contribute to birthorder-associated reductions in immune-mediated disease prevalence.

\section{Key words}

Parity number, neonates, T cells, immune regulation, in utero programming

\section{Contributions}

The guarantor of the study is HB who has been responsible for the integrity of the work as a whole, from conception and design to acquisition of data, analysis and writing of the manuscript. MK contributed to acquisition of data, performed classical statistical analysis as well as multivariate data analysis and wrote the manuscript. JML, AHT and SB contributed to conception, design and acquisition of data and writing of the manuscript. HMW contributed to acquisition of data. MAR contributed to data analysis. All co-authors have contributed to the analysis and interpretation of the data, and have provided important intellectual input and approval of the final version of the manuscript. Competing interests: The authors have no conflict of interest. 
64

65 APC

66

$67 \mathrm{CD}$

68 CD40L:

69 CTL:

$70 \quad$ FITC

71 GLM

72 ICOS

73 IFN- $\gamma$ :

74 IL:

75 MFI:

76 PC:

77 PCA:

78 PE:

79 PC7:

80 PE-Cy7:

81 PHA:

82 Th:

83 TNF- $\alpha$ :

84 Tregs:

$85 \operatorname{Tr} 1:$

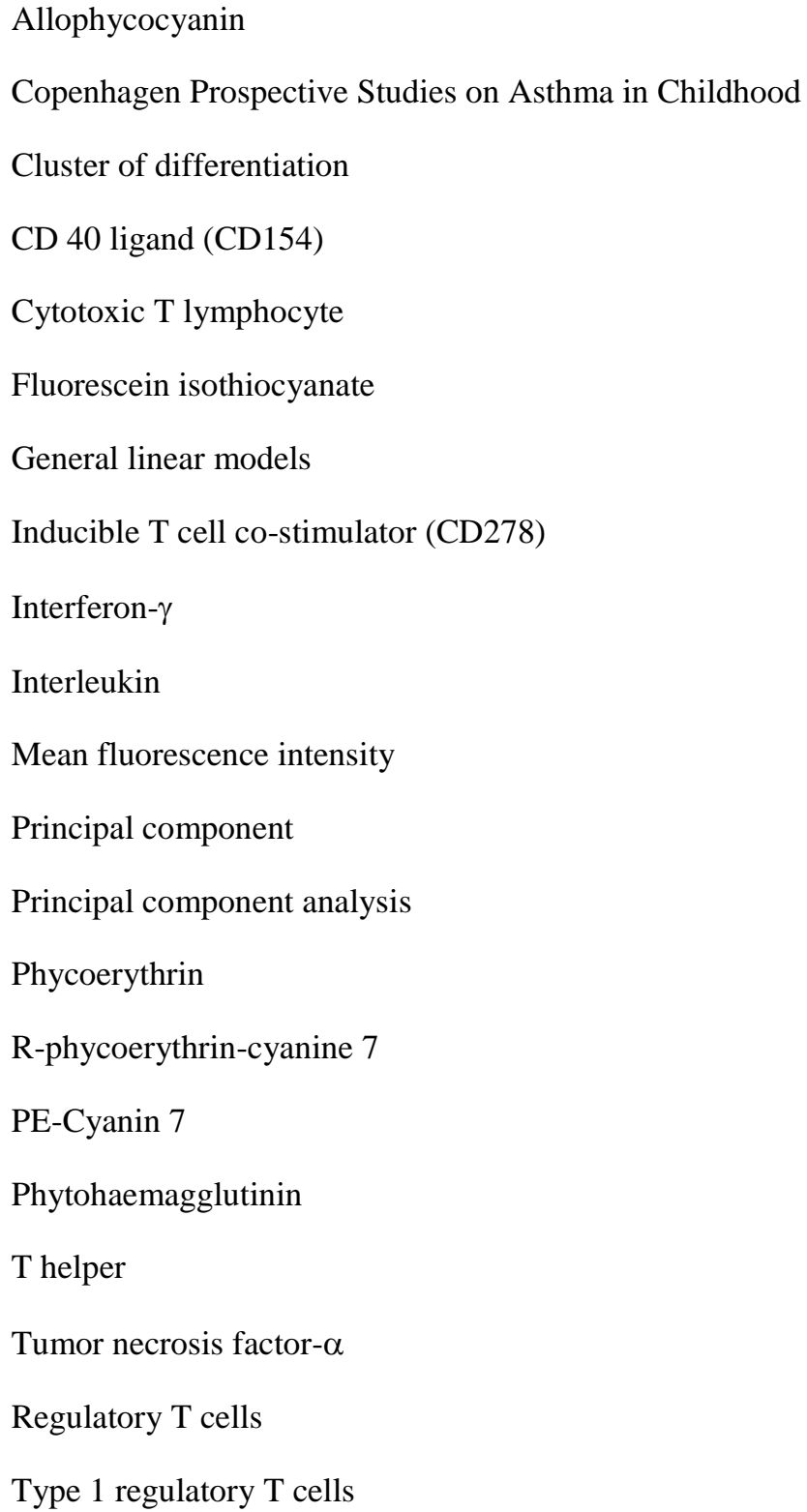


A 'birth-order-effect' on disease risk has been known for several decades (1) relating to a higher risk in the first-born child for a number of diseases including lymphoma (2), testicular cancer (3,4), type 1 diabetes mellitus (5), eczema, rhinitis and asthma (6-8). Since these diseases are all influenced by dysfunctional immune activation, we hypothesized that the birth-order may affect early immune function and be programmed already during pregnancy.

Throughout pregnancy the mother's immune system is challenged by the hemi-allogeneic fetus and in order to accomplish a successful pregnancy her immune system is dynamically modulated from conception to delivery (9). Essential for implantation and maintenance of pregnancy is several hormones, including estrogen, which presumably promotes expansion of regulatory $\mathrm{T}$ cells (Tregs) and production of anti-inflammatory interleukin-10 (IL-10) within the mother as well as at the maternal-fetal interface (10-14). It is also reported that long-lasting fetus-specific immune cells develop in maternal circulation during pregnancy $(15,16)$ and rapidly expand in secondary pregnancies with the same father $(17)$. An increased number of Tregs specific for paternal antigens is found in secondary pregnancies (18). Alltogether this suggests that an increased immune suppression occurs in multiparous women. In relation to the general maternal-fetal interplay, it is reported that anti-inflammatory, but not pro-inflammatory, mediator levels correlate between the pregnant mother and her fetus (19), as does estrogen levels (20). These findings support a bidirectional immunological reflection of an anti-inflammatory milieu between mother and child. It is, however, unknown if changes in this maternal-fetal tolerance of newborns with increased birth numbers are a result of in utero programming of immune function.

We aimed to study if $\mathrm{T}$ cell function are differentially encoded in newborns of primiparous (first pregnancy) and multiparous (second or more pregnancies) mothers. We purified T cells 
from cord blood and stimulated these with anti-CD3/CD28-coated beads to induce polyclonal stimulation. $\mathrm{T}$ cell function was assessed by measurement of seven activation markers on $\mathrm{CD}^{+}$helper and $\mathrm{CD}^{+}$cytotoxic $\mathrm{T}$ cells, respectively. Secreted cytokines characteristic of T helper 1 (Th1) cell (interferon- $\gamma$ (IFN- $\gamma$ ), tumor necrosis factor- $\alpha$ (TNF$\alpha)$ ), Th2 cell (IL-4, IL-5, IL-13), Th 17 cell (IL-17) and Tregs (IL-10) immunity were measured in supernatants. Moreover, we characterized the percentage of $\mathrm{CD}^{+} \mathrm{CD} 25^{+} \mathrm{T}$ cells within unstimulated cord blood $\mathrm{T}$ cells. These parameters of $\mathrm{T}$ cell function were studied in relation to maternal parity to examine if in utero programming of the T cell compartment is influenced by birth-order. 


\section{METHODS}

\section{Study population}

A total of 28 full-term, healthy neonates born from September 2009 to March 2010 were enrolled in this study. The neonates were part of the ongoing unselected Copenhagen Prospective Study on Asthma in Childhood 2010 birth-cohort (COPSAC 2010 ) of 700 children recruited in Zealand, Denmark, during 2009-2010 (21). Parental atopy was defined from a history of doctor-diagnosed asthma, rhinitis, and/or atopic dermatitis. This was determined by structured clinical interviews performed by the research doctors in gestation week 24 . The study was conducted in accordance with the guiding principles of the Declaration of Helsinki and approved by the Ethics Committee for Copenhagen (H-B-2008-093) and the Danish Data Protection Agency (j.nr. 2008-41-2599). Both parents gave their informed consent before enrollment of the child.

\section{Cord blood sampling and shipment}

Cord blood was collected postpartum by needle puncture of the umbilical vein. The blood was stored in a citrate phosphate dextrose-containing bag (catalog 791-01U, Pall, NY) and immediately transported to the laboratory by courier and processed within 24 hours after birth.

\section{$T$ cell purification and activation}

Cord blood $\mathrm{CD}^{+}{ }^{\mathrm{T}}$ cells were isolated using the Dynabeads ${ }^{\circledR}$ FlowComp ${ }^{\mathrm{TM}}$ Human CD3 kit (Invitrogen, Carlsbad, CA) according to the manufacturer's instructions. In brief, T cells were purified from $40 \times 10^{6}$ total nucleated cord blood cells by positive selection using antiCD3 antibody and magnetic beads. To release $\mathrm{CD}^{+}$cells from beads, cells were incubated with FlowComp ${ }^{\mathrm{TM}}$ Release Buffer. For all individuals, the purity of $\mathrm{CD}^{+} \mathrm{T}$ cells was 
determined to be greater than $98 \%$ by flow cytometry (anti-CD3/APC-eFlour780 antibody (eBioscience, San Diego, CA)).

Isolated T cells were cultured $\left(10^{6}\right.$ cells/mL, $200 \mathrm{ul}$ in 96 U-bottomed plates) and activated using Dynabeads ${ }^{\circledR}$ Human T-Expander CD3/CD28 (Invitrogen) in complete medium (RPMI 1640 containing 2 mM L-glutamine, 10\% heat-inactivated fetal bovine serum, $100 \mathrm{U} / \mathrm{mL}$ penicillin, $100 \mathrm{ug} / \mathrm{mL}$ streptomycin (all from Lonza)). Control conditions were unstimulated T cells. Cultures were kept in a humidified $37^{\circ} \mathrm{C}, 5 \% \mathrm{CO}_{2}$ incubator for $24 \mathrm{~h}$.

\section{T cell activation markers}

T cell surface expression of activation markers CD25, CD27, CD30, CD69, CD71, CD154 (CD40L) and CD278 (ICOS) was determined on $\mathrm{CD}^{+} \mathrm{CD}^{+}$helper and $\mathrm{CD}^{+} \mathrm{CD}^{+}$ cytotoxic T cells following activation. $4 \times 10^{5} \mathrm{~T}$ cells were stained in FACS buffer (PBS, $0.1 \%$ sodium azide, $1 \%$ heat-inactivated fetal bovine serum for $30 \mathrm{~min}$ at $4^{\circ} \mathrm{C}$ using the following antibodies: Fluorescein isothiocyanate (FITC)-conjugated anti-hCD71, RPhycoerythrin (PE)-conjugated anti-hCD69, PE-anti-hCD30, PE-Cyanin 7 (PE-Cy7)conjugated anti-hCD278, allophycocyanin eFluor 780 (APC-eFlour780)-anti-hCD3, eFlour 450-conjuated anti-hCD4 (all from eBioscience), R-Cy7-anti-hCD25 (Beckman Coulter, Fullerton, CA), Amcyan-conjugated anti-hCD8 (BD Biosciences, Franklin Lakes, NJ), AlexaFlour647 anti-hCD27 and AlexaFlour488 anti-hCD154 (BioLegend, San Diego, CA). Cells were analyzed on a BD FACSCanto ${ }^{\mathrm{TM}}$ II (BD Biosciences) followed by data analysis in FlowJo v.7.6.5 (Tree Star, Ashland, OR). The surface marker expression levels were determined as the mean fluorescence intensity (MFI) in both stimulated and unstimulated T cells. The percentages of $\mathrm{CD}^{+} \mathrm{CD} 25^{+}$and $\mathrm{CD}^{+} \mathrm{CD} 25^{+} \mathrm{T}$ cells were determined in unstimulated samples. Representative histograms of surface marker expressions before and after activation can be found in Supplementary Figure S1. 


\section{T cell effector cytokine production}

Supernatants were collected $24 \mathrm{~h}$ after initiation of poly-clonal T cell activation and stored at $-80^{\circ} \mathrm{C}$ until analysis. The level of IFN- $\gamma$, TNF- $\alpha$, IL-4, IL-5, IL-10, IL-13 and IL-17A (IL17) were measured in supernatants using a custom Meso Scale Discovery Multi-plex human cytokine assay (Meso Scale Discovery, Gaithersburg, MD). Assays were performed according to manufacturer's recommendations, but included sample incubation over night at $4^{\circ} \mathrm{C}$ on shaker and the use of an eight-point standard curve $(0.65-10,000 \mathrm{pg} / \mathrm{mL})$ for increased sensitivity and dynamic range. Samples were read using the Sector Imager 6000 (Meso Scale Discovery). Detection limits were measured in $\mathrm{pg} / \mathrm{mL}$, calculated as mean of blanks $+3 x$ standard deviation and were as follows: IFN- $\gamma: 0.93$, TNF- $\alpha: 0.66$, IL-4: 0.88, IL-5: 0.65, IL-10: 0.76, IL-13: 4.1 and IL-17: 1.7. Signals from unstimulated T cells were below the detection limit. Signals below the lower detection limit were set to $0.5 \mathrm{x}$ the lower detection limit and samples with zero values were set to $0.1 \mathrm{x}$ the lower detection limit. For IL-4, $21 \%$ of the measurements were below the detection level, and $11 \%$ were undetectable; for IL-5, $18 \%$ of the measurements were below the detection level; for IL-17, $11 \%$ of the measurements were below the detection level and 25\% were undetectable.

\section{Statistical analyses of immune mediator measurements}

Data was analyzed by conventional statistics and explored using principal components analysis (PCA). If needed, effector mediator levels were log-transformed before analysis to obtain normality distribution. Differences in immune mediator levels between groups by sex, maternal parity and parental atopy were tested by unpaired Student's t-test. General linear models (GLM) were applied with immune mediator levels as dependent variables and sex, parity and parental atopy as independent covariates (Supplementary Table S1). Estimates of 
scaled, adjusted dependent variables (z-scores) were expressed as differences between groups with corresponding 95\% confidence intervals.

PCA was applied to all 21 variables of T cell activation markers and cytokines after scaling. The first principal component (PC1) in the PCA accounts for the largest variation in the dataset; the second principal component (PC2) accounts for the second largest variation in data, and so forth. Projections of data onto PCs reveal new underlying latent variables (the scores). By use of a PCA algorithm, we obtained the PCs describing the systematic variation in data across the 21 variables; hence revealing the biological profiles that dominate the dataset. We applied the scores as dependent variables in the uni- and multivariate statistical analysis.

Statistical significance was defined by $\mathrm{P}<0.05$. We used Bonferroni correction separately on the two measured compartments: cytokines and surface markers. The PCA further surpassed multiple testing issues by reducing the number of variables to a few latent factors. Data processing was performed with R v. 2.15.3 software (http:/www.R-project.org, R Development Core Team, Vienna, Austria). PCA results were illustrated by use of the R add-on Ade4 package (22). 


\section{RESULTS}

\section{Study population characteristics}

The study population is part of the COPSAC 2010 cohort and included 28 full-term healthy neonates born in the period from September to March. Baseline characteristics of the neonates enrolled in the study cohort did not differ significantly from neonates of the full cohort with respect to factors that may confound the present study: sex, primiparity, maternal atopy and paternal atopy (Table 1).

\section{Birth-order influences CD25 expression and IL-10 levels in activated cord blood T cells}

Activated cord blood $\mathrm{T}$ cells from first-born infants were found to produce lower IL-10 levels $(\mathrm{P}=0.007)$ and display reduced $\mathrm{CD} 25$ expression on $\mathrm{CD} 4^{+}$helper $\mathrm{T}$ cells $(\mathrm{P}=0.0003)$ as compared to those of later-born infants (Figure 1). None of the other T cell cytokines or activation markers differed by birth-order (Figure 1). IL-10 production and CD25 expression on $\mathrm{CD}^{+}$helper $\mathrm{T}$ cells were also found to be significantly different in first-born infants compared to those of later-born after adjusting for sex and parental atopy (Table 2 and 3). Sex and parental atopy was not associated with cytokine production or activation marker expression levels in activated cord blood T cells (Table 2 and 3).

The percentage of $\mathrm{CD}^{+}$helper and $\mathrm{CD}^{+}$cytotoxic $\mathrm{T}$ cells within the pool of cord blood $\mathrm{CD}^{+} \mathrm{T}$ cells were unaffected by primiparity as well as sex and parental atopy (Table 3). The general activation characteristics and correlations between the twenty-one $\mathrm{T}$ cell functional parameters of activated cord blood T cells are displayed in Supplementary Figure S2-S4.

We found that IL-10 levels positively correlated with the expression of CD25 on CD4 ${ }^{+}$ helper $\mathrm{T}$ cells in activated cord blood $\mathrm{T}$ cells (Figure $2, \mathrm{P}=0.006$ ). Consistent with the 
univariate analysis in Figure 1; first-born infants displayed lower IL-10 and CD25 expression compared to later-born infants (Figure 2).

We then tested if increased IL-10 production and CD25 expression on CD4 ${ }^{+} \mathrm{T}$ cells was associated with enhanced numbers of resting $\mathrm{CD} 4^{+} \mathrm{CD} 25^{+}$in cord blood that may represent Treg. An apparent $\mathrm{CD}^{+} \mathrm{CD}^{2} 5^{+}$population was identifiable in unstimulated cord blood $\mathrm{T}$ cells (Figure 3A). As CD25 can also be a marker for recent activation, we also analyzed for CD25 expression levels on unstimulated $\mathrm{CD}^{+} \mathrm{T}$ cells that would be apparent if cord blood T cells were activated in vivo. No CD25 expression was found on unstimulated CD8 ${ }^{+} \mathrm{T}$ cells (Figure 3B), suggesting that the cord blood $\mathrm{CD} 4{ }^{+} \mathrm{CD} 25^{+}$cells represent a Treg subset, and not readily activated $\mathrm{T}$ cells present within cord blood. When comparing the percentage of circulating cord blood $\mathrm{CD} 4^{+} \mathrm{CD} 25^{+}$cells in first-born and later-born infants, we found no differences (Table 3). However, the percentage of cord blood CD4 ${ }^{+} \mathrm{CD} 25^{+}$cells was found to correlate positively with the levels of secreted IL-10 in activated T cells $(P=0.006$, Figure 3C), and also with TNF- $\alpha(\mathrm{P}=0.0006), \mathrm{IL}-13(\mathrm{P}=0.0008)$, IL-5 $(\mathrm{P}=0.048)$, and IL-4 $(\mathrm{P}=$ 0.012) (data not shown), but all these correlations were independent of birth-order (Figure 3C).

\section{The birth-order affects the general profile of activated cord blood $T$ cells}

In support of the conventional statistics, the PCA identified differences in overall surface marker and cytokine response levels between first-born and later-born neonates, respectively (Figure 4). Principal Component (PC) 1 was found to explain 27\% of the variation in the data and to separate overall cytokines from surface markers (PC1, Figure 4B), but these patterns remained largely similar in first-born and later-born infants (PC1, Figure 4E). On the other hand, PC2, which explained $18 \%$ of the data variation, showed to separate T cell immunity in first-born and later-born infants $(\mathrm{P}=0.02$, $\mathrm{PC} 2$, Figure $4 \mathrm{E})$. Uniting the score 
251

252

plot (Figure 4A) and loading plot (Figure 4B) for PC1 and PC2 again illustrated the correlation of IL-10 and $\mathrm{CD}^{+} \mathrm{CD} 25^{+}$and their combined impact on the separation by maternal parity.

PC3, explaining $15 \%$ of the variation in data, appeared to cluster Th2 markers (CD30, CD278, IL-4, IL-5, IL-13), Treg (CD25, IL-10) and Th17 (IL-17), while separating them from Th1 markers (IFN- $\gamma$, TNF- $\alpha$, CD154 and early activation (CD69)) (PC3, Figure 4C \& D). PC3 did not relate to the birth-order (Figure 4E). 


\section{DISCUSSION}

\section{Main findings}

We identified a functional divergence in activated cord blood $\mathrm{T}$ cells relating to birth-order. T cells from first-born children exhibited reduced IL-10 production and CD25 expression on CD4 helper T cells following activation. This weakened anti-inflammatory profile in higher birth-order newborns did not relate to the relative number of resting cord blood CD $4^{+} \mathrm{CD} 25^{+}$ $\mathrm{T}$ cells. Our findings imply that first-born newborns possess a $\mathrm{T}$ cell compartment that is programmed at birth to respond with lower IL-10 and CD25 expression in CD4 ${ }^{+} \mathrm{T}$ cells upon stimulation as compared to second or later born children. Such changes could likely impact immune function and handling of environmental exposures during early life, and may as such influence later disease risk in first-born offspring.

\section{Study strengths and limitations}

It is a strength of this study that we used purified cord blood T cells allowing us to examine in utero imprinted properties of the $\mathrm{T}$ cell compartment without inference from other immune cells present in cord blood (23). Accordingly, we were able to document a clear in utero imprinting of the functional response from $\mathrm{T}$ cells by birth-order. To our knowledge this has not previously been demonstrated. We used anti-CD3/28-coated beads to polyclonally activate all subtypes of cord blood $\mathrm{T}$ cells. These beads mimic antigenpresenting cells and are believed to activate $\mathrm{T}$ cells in a physiological manner compared to more commonly used agents like Staphylococcus enterotoxin B, PMA/ionomycin and phytohemagglutinin (PHA). Addressing several $\mathrm{T}$ cell parameters such as $\mathrm{T}$ cell cytokines and surface activation marker expression allowed us, in a comprehensive manner, to identify specific functional entities affected by parity number. We tested for seven different 
cytokines that promote immunity to intracellular pathogens (type-1; IFN- $\gamma$, TNF- $\alpha$ ), extracellular pathogens (type-17; IL-17), helminthes (type-2; IL-4, IL-5, IL-13), as well as immune regulation (IL-10). These cytokine measures were combined with identification of the level of expression of seven surface markers on activated T cells (CD25, CD27, CD30, CD69, CD71, CD154, CD278) that are all enhanced during proliferation, but of which we have yet limited insight into in regard to their exact involvement in specific types of immune responses.

Based on our present finding pointing towards a reduced anti-inflammatory function in firstborn newborns, it is a limitation that we did not perform a detailed characterization of Tregs in the cord blood of these newborns. Although no human lineage specific marker of Treg exists (24), CD25 ${ }^{\text {hi }}$ FoxP $3^{+}$CD $127^{\text {lo }}$ are generally accepted as markers of Tregs (24). As we did not look specifically for Treg identification in this study, we had only data available for CD25. We therefore used CD25 expression patterns in unstimulated cord blood T cells to make a proxy for the percentage of Tregs (identified as $\mathrm{CD}^{+} \mathrm{CD} 25^{+}$) in cord blood. CD25 is constitutively expressed on Tregs, whereas activated effector T cells up-regulate CD25 expression. Since we observed no activation of $\mathrm{CD}^{+} \mathrm{T}$ cells in unstimulated cord blood, we used this observation to imply that the number of recently activated effector $\mathrm{CD}^{+} \mathrm{T}$ cells (with $\mathrm{CD} 25^{+}$) would accordingly be low in the cord blood of these infants. This is in line with earlier studies that have identified only very few activated T cells in cord blood (25). Thus, we assumed that the $\mathrm{CD} 4^{+} \mathrm{CD} 25^{+}$subset identified here represent cord blood Tregs. This is further supported by a comparable percentage of $\mathrm{CD} 4^{+} \mathrm{CD} 25^{+}$Treg cells in a previous study (26).

\section{Interpretation}


Our current finding supports the assumption that $\mathrm{T}$ cell functional properties of the newborn immune response are programmed in utero (27-29), and that birth-order may influence these priming events $(27,30)$. We demonstrate that first-born infants display a reduced antiinflammatory profile in $\mathrm{T}$ cells at birth. This suggests that immune regulatory mechanisms inducing maternal-fetal tolerance in the mother during pregnancy affects immune function in the offspring. This notion is also supported by a previous study showing a correlation of anti-inflammatory, but not pro-inflammatory, cytokines between mother and child (19).

The pleiotropic cytokine IL-10 that was decreased in activated $\mathrm{T}$ cells from first-born neonates has significant immune-modulatory properties affecting a broad range of immune and non-immune cells (reviewed in $(31,32)$ ). IL-10 is well-known for its repression of proinflammatory responses and limitation of inflammation-induced tissue disruption. A recent study, suggests that IL-10 itself may be important for Treg homeostasis in pregnancy (19). This may explain our current finding of a general correlation between the percentage of $\mathrm{CD}^{+} \mathrm{CD} 25^{+}$cells in cord blood T cells and the secretion of IL-10 from stimulated $\mathrm{T}$ cells, irrespective of parity.

Up-regulation of CD25 (IL2R $\alpha$ ) expression is necessary for proliferation and differentiation of naïve $\mathrm{T}$ cells into effector $\mathrm{T}$ cells upon antigenic activation by antigen-presenting cells. Enhanced CD25 expression levels on $\mathrm{CD}^{+} \mathrm{T}$ cells, without concomitant increase in other markers, is indicative of improved activity of a specific subset of $\mathrm{CD}^{+} \mathrm{T}$ cells with suppressive properties (reviewed in $(24,33)$ ). Indeed, Tregs can suppress activation of bystander T cells by up-regulating CD25 expression to scavenge IL-2 important for expansion of pro-inflammatory T cells. We observed an increased CD25 expression on CD4 ${ }^{+} \mathrm{T}$ cells and an enhanced IL-10 secretion into culture medium, and speculate that a specific Treg cell subset could be responsible for this phenotype. One such subset could be the induced IL-10- 
producing Tr1 subset that is itself promoted by IL-10 (34). Although it remains to be demonstrated, we speculate that transfer of the anti-inflammatory pregnancy milieu from mother to fetus may promote induction of regulatory Tr1 cells in the offspring, and that this specific subset may increase by birth-order. However, based on our exploratory experimental setup, we did not specifically examine the expansion and function of certain Treg populations. It will be of great interest to delineate this in future studies, since elucidation of the basis of in utero regulatory mechanisms could be of central importance to understand the reduced disease risk in higher-birth-order infants. We also speculate that enhanced IL-10 secretion from activated $\mathrm{T}$ cells after birth could confer some protection against excessive tissue pathology after exposure to infectious microbes, as well as increasing the level of peripheral tolerance to self and non-self antigens (35). Such disease-protective mechanisms could play part in the reduced disease risk seen in higher-birth-order infants (1).

It is widely believed that the birth-order-effect on disease risk arises due to postnatal exposures associated with having older children in the household, conceptualized by the hygiene hypothesis (36). The possibility of effects related to in utero priming of immunity as a cause of previous carriage of older siblings has received less attention. In the current study, we show that in utero priming of a $\mathrm{T}$ cell functional bias occurs before postnatal exposure to older siblings/children. Whether the factors mediating this effect is related to enhanced maternal exposure to infections during pregnancy (due to a higher microbial burden carried by older siblings), as proposed by Karmaus et al. (30), by feto-maternal communication of immunosuppressive mechanisms as a cause of the increased number of Tregs specific for paternal antigens found in secondary pregnancies (18), or by yet unidentified mechanisms still remain to be demonstrated. Based on our current results, it will however, be of interest to increase the focus on elucidation of the underlying mechanism as well as its contribution to in utero immune priming in shaping the risk of birth-order-affected diseases. 
355 In conclusion, our present finding of decreased IL-10 secretion and CD25 expression on $356 \mathrm{CD}^{+}$helper $\mathrm{T}$ cells in first-born children demonstrates that programming of $\mathrm{T}$ cells takes 357 place in utero and depends on the number of maternal pregnancies. This finding may 358 partially explain the enhanced risk of developing immune-related diseases in first-born 359 individuals. 


\section{ACKNOWLEDGMENTS}

361 The authors thank the children and parents participating in the COPSAC 2010 cohort and the 362 COPSAC study team, as well as technician Lisbeth Buus Rosholm, Technical University of Denmark. We also thank the Lundbeck Foundation; Danish State Budget; Danish Council

364 for Strategic Research; The Danish Council for Independent Research and The Capital Region Research Foundation for funding COPSAC. 


\section{REFERENCES}

1. Golding J, Peters T. Eczema and hay fever. In: Butler N, Golding J, editors. From Birth to five, a study Heal. Behav. Britain’s 5-year-olds. Pergamon Press; 1986. p. 171-86.

2. Becker N, de Sanjose S, Nieters A, Maynadié M, Foretova L, Cocco PL, et al. Birth order, allergies and lymphoma risk: results of the European collaborative research project Epilymph. Leuk. Res. 2007 Oct;31(10):1365-72.

3. Westergaard T, Andersen PK, Pedersen JB, Frisch M, Olsen JH, Melbye M. Testicular cancer risk and maternal parity: a population-based cohort study. Br. J. Cancer. 1998 Apr;77(7):1180-5.

4. Prener A, Hsieh CC, Engholm G, Trichopoulos D, Jensen OM. Birth order and risk of testicular cancer. Cancer Causes Control. 1992 May;3(3):265-72.

5. Cardwell CR, Stene LC, Joner G, Bulsara MK, Cinek O, Rosenbauer J, et al. Birth order and childhood type 1 diabetes risk: a pooled analysis of 31 observational studies. Int. J. Epidemiol. 2011 Apr;40(2):363-74.

6. Karmaus W, Botezan C. Does a higher number of siblings protect against the development of allergy and asthma? A review. J Epidemiol Community Heal. 2002;56:209-17.

7. Kinra S, Davey Smith G, Jeffreys M, Gunnell D, Galobardes B, McCarron P. Association between sibship size and allergic diseases in the Glasgow Alumni Study. Thorax. 2006 Jan;61(1):48-53.

8. Westergaard T, Rostgaard K, Wohlfahrt J, Andersen PK, Aaby P, Melbye M. Sibship characteristics and risk of allergic rhinitis and asthma. Am. J. Epidemiol. 2005 Jul 15;162(2):125-32.

9. Mor G, Cardenas I, Abrahams V, Guller S. Inflammation and pregnancy: the role of the immune system at the implantation site. Ann N Y Acad Sci. 2011;1221(1):80-7.

10. Mao G, Wang J, Kang Y, Tai P, Wen J, Zou Q, et al. Progesterone increases systemic and local uterine proportions of CD4+CD25+ Treg cells during midterm pregnancy in mice. Endocrinology. 2010 Nov;151(11):5477-88.

11. Polanczyk MJ, Carson BD, Subramanian S, Afentoulis M, Vandenbark A a, Ziegler SF, et al. Cutting edge: estrogen drives expansion of the CD4+CD25+ regulatory $\mathrm{T}$ cell compartment. J. Immunol. 2004 Aug 15;173(4):2227-30.

12. Piccinni MP, Beloni L, Livi C, Maggi E, Scarselli G, Romagnani S. Defective production of both leukemia inhibitory factor and type 2 T-helper cytokines by decidual T cells in unexplained recurrent abortions. Nat. Med. 1998 Sep;4(9):1020-4. 
13. Schumacher A, Brachwitz N, Sohr S, Engeland K, Langwisch S, Dolaptchieva M, et al. Human chorionic gonadotropin attracts regulatory $\mathrm{T}$ cells into the fetal-maternal interface during early human pregnancy. J. Immunol. 2009 May 1;182(9):5488-97.

14. Carbone F, Procaccini C, De Rosa V, Alviggi C, De Placido G, Kramer D, et al. Divergent immunomodulatory effects of recombinant and urinary-derived FSH, LH, and hCG on human CD4+ T cells. J. Reprod. Immunol. Elsevier Ireland Ltd; 2010 Jun;85(2):172-9.

15. Lissauer D, Piper K, Goodyear O, Kilby MD, Moss P a H. Fetal-specific CD8+ cytotoxic T cell responses develop during normal human pregnancy and exhibit broad functional capacity. J. Immunol. 2012 Jul 15;189(2):1072-80.

16. Van Kampen C a, Versteeg-van der Voort Maarschalk MF, Langerak-Langerak J, van Beelen E, Roelen DL, Claas FH. Pregnancy can induce long-persisting primed CTLs specific for inherited paternal HLA antigens. Hum. Immunol. 2001 Mar;62(3):201-7.

17. Arck PC, Hecher K. Fetomaternal immune cross-talk and its consequences for maternal and offspring's health. Nat. Med. Nature Publishing Group; 2013 May;19(5):548-56.

18. Prescott SL, Taylor a, Roper J, Wahdan a, Noakes P, Thornton C, et al. Maternal reactivity to fetal alloantigens is related to newborn immune responses and subsequent allergic disease. Clin. Exp. Allergy. 2005 Apr;35(4):417-25.

19. Santner-Nanan B, Straubinger K, Hsu P, Parnell G, Tang B, Xu B, et al. Fetalmaternal alignment of regulatory T cells correlates with IL-10 and Bcl-2 upregulation in pregnancy. J. Immunol. 2013 Jul 1;191(1):145-53.

20. Troisi R, Potischman N, Roberts JM, Samples UC, Troisi R, Potischman N, et al. Correlation of Serum Hormone Concentrations in Maternal and Umbilical Cord Samples. Cancer Epidemiol. Biomarkers Prev. 2003;12:452-6.

21. Bisgaard H, Vissing NH, Carson CG, Bischof AL, Følsgaard N V, Kreiner-Møller E, et al. Deep Phenotyping of the Unselected COPSAC2010 Birth Cohort Study. Clin. Exp. allergy. 2013 Oct 7;43(12):1384-94.

22. Dray S, Dufour A-B. The ade4 Package: Implementing the Duality Diagram for Ecologists. J. Stat. Softw. 2007;22(4):1-20.

23. Fievet N, Varani S, Ibitokou S, Briand V, Louis S, Perrin RX, et al. Plasmodium falciparum exposure in utero, maternal age and parity influence the innate activation of foetal antigen presenting cells. Malar. J. 2009 Jan;8:251.

24. Schmetterer KG, Neunkirchner A, Pickl WF. Naturally occurring regulatory T cells: markers, mechanisms, and manipulation. FASEB J. 2012 Jun;26(6):2253-76.

25. Lee Y-S, Kim T-S, Kim D-K. T lymphocytes derived from human cord blood provide effective antitumor immunotherapy against a human tumor. BMC Cancer. BioMed Central Ltd; 2011 Jan;11(1):225. 
26. Mayer E, Bannert C, Gruber S, Klunker S, Spittler A, Akdis C a, et al. Cord blood derived CD4+ CD25(high) $\mathrm{T}$ cells become functional regulatory $\mathrm{T}$ cells upon antigen encounter. PLoS One. 2012 Jan;7(1):e29355.

27. Devereux G, Barker RN, Seaton a. Antenatal determinants of neonatal immune responses to allergens. Clin. Exp. Allergy. 2002 Jan;32(1):43-50.

28. Latzin P, Frey U, Armann J, Kieninger E, Fuchs O, Röösli M, et al. Exposure to moderate air pollution during late pregnancy and cord blood cytokine secretion in healthy neonates. PLoS One. 2011 Jan;6(8):e23130.

29. Schaub B, Liu J, Höppler S, Schleich I, Huehn J, Olek S, et al. Maternal farm exposure modulates neonatal immune mechanisms through regulatory T cells. J. Allergy Clin. Immunol. 2009 Apr;123(4):774-82.e5.

30. Karmaus W, Arshad H, Mattes J. Does the sibling effect have its origin in utero? Investigating birth order, cord blood immunoglobulin E concentration, and allergic sensitization at age 4 years. Am. J. Epidemiol. 2001 Nov 15;154(10):909-15.

31. Saraiva M, O’Garra A. The regulation of IL-10 production by immune cells. Nat. Rev. Immunol. Nature Publishing Group; 2010 Mar;10(3):170-81.

32. Couper KN, Blount DG, Riley EM. IL-10: the master regulator of immunity to infection. J. Immunol. 2008 May 1;180(9):5771-7.

33. Létourneau S, Krieg C, Pantaleo G, Boyman O. IL-2- and CD25-dependent immunoregulatory mechanisms in the homeostasis of T-cell subsets. J. Allergy Clin. Immunol. 2009 Apr;123(4):758-62.

34. Levings MK, Sangregorio R, Galbiati F, Squadrone S, de Waal Malefyt R, Roncarolo MG. IFN-alpha and IL-10 induce the differentiation of human type 1 T regulatory cells. J. Immunol. 2001 May 1;166(9):5530-9.

35. Raedler D, Illi S, Pinto LA, von Mutius E, Illig T, Kabesch M, et al. IL10 polymorphisms influence neonatal immune responses, atopic dermatitis, and wheeze at age 3 years. J. Allergy Clin. Immunol. Elsevier Ltd; 2012 Sep 26;131(3):789-96.

36. Strachan DP. Hay fever, hygiene, and household size. Br. Med. J. 1989;299(November):1259-60. 


\section{TABLES \& FIGURES}

Table 1. Characteristics of the study population.

\begin{tabular}{|c|c|c|c|}
\hline & $\begin{array}{l}\text { Study cohort } \\
\qquad \mathrm{n}=28 \\
\end{array}$ & $\begin{array}{c}\text { COPSAC }_{2010} \text { cohort } \\
n=618 \\
\end{array}$ & P-value $^{\text {a }}$ \\
\hline \multicolumn{4}{|l|}{$\operatorname{Sex}(n(\%))$} \\
\hline Male & 17 (61\%) & 313 (51\%) & \\
\hline Female & $11(39 \%)$ & 305 (49\%) & 0.338 \\
\hline \multicolumn{4}{|c|}{ Parity (n(\%)) } \\
\hline Primi & $14(50 \%)$ & $293(47 \%)$ & \\
\hline Multi & $14(50 \%)$ & $325(53 \%)$ & 0.848 \\
\hline \multicolumn{4}{|c|}{ Maternal Atopy (n(\%)) } \\
\hline Yes & $18(64 \%)$ & 295 (48\%) & \\
\hline No & $10(36 \%)$ & $323(52 \%)$ & 0.248 \\
\hline \multicolumn{4}{|c|}{ Paternal Atopy (n(\%)) } \\
\hline Yes & $10(36 \%)$ & 346 (56\%) & \\
\hline No & $18(64 \%)$ & $272(44 \%)$ & 0.440 \\
\hline
\end{tabular}


Table 2. Influence of prenatal factors on cytokine secretion in activated cord blood T cells of healthy neonates.

\begin{tabular}{ccccccc}
\hline $\mathbf{I F N -}^{\mathbf{a}}$ & $\mathbf{I L - 1 0}^{\mathbf{a}}$ & $\mathbf{I L - 4}^{\mathbf{b}}$ & $\mathbf{I L - 5}^{\mathbf{a}}$ & $\mathbf{I L - 1 3}^{\mathbf{a}}$ & $\mathbf{I L - 1 7}^{\mathbf{b}}$ & $\mathbf{T N F}^{\mathbf{a}}$ \\
$(\mathrm{pg} / \mathrm{mL})$ & $(\mathrm{pg} / \mathrm{mL})$ & $(\mathrm{pg} / \mathrm{mL})$ & $(\mathrm{pg} / \mathrm{mL})$ & $(\mathrm{pg} / \mathrm{mL})$ & $(\mathrm{pg} / \mathrm{mL})$ & $(\mathrm{pg} / \mathrm{mL})$ \\
\hline
\end{tabular}

Sex

$\begin{array}{lrrrrrrr}\text { Male }(\mathrm{n}=17) & 75.4 & 22.9 & 2.2 & 1.9 & 259 & 3.0 & 1010 \\ \text { Female }(\mathrm{n}=11) & 98.5 & 26.0 & 3.9 & 2.2 & 254 & 4.2 & 1266 \\ \text { P-value } & 0.905 & 0.395 & 0.430 & 0.667 & 0.605 & 0.611 & 0.314 \\ \text { Adj. P-value }^{\mathrm{c}} & 0.963 & 0.300 & 0.653 & 0.761 & 0.872 & 0.831 & 0.246\end{array}$

\section{Parity}

$\begin{array}{lrrrrrrr}\text { Primi }(\mathrm{n} \mathrm{=14)} & 100.6 & 18.0 & 1.9 & 1.5 & 207 & 2.9 & 1055 \\ \text { Multi }(\mathrm{n}=14) & 68.4 & 30.2 & 3.7 & 2.6 & 307 & 4.1 & 1167 \\ & & & & & & \\ \text { P-value } & 0.482 & \mathbf{0 . 0 0 7} & 0.069 & 0.170 & 0.067 & 0.246 & 0.636 \\ \text { Adj. P-value }^{\mathbf{c}} & 0.405 & \mathbf{0 . 0 1 1} & 0.105 & 0.198 & 0.170 & 0.378 & 0.746\end{array}$

\section{Maternal Atopy}

$\begin{array}{lrrrrrrr}\text { Yes }(\mathrm{n}=18) & 81.2 & 26.0 & 3.3 & 2.3 & 297 & 3.5 & 1146 \\ \text { No }(\mathrm{n}=10) & 90.5 & 20.6 & 2.0 & 1.6 & 185 & 3.6 & 1048 \\ \text { P-value } & 0.638 & 0.573 & 0.524 & 0.670 & 0.068 & 0.832 & 0.679 \\ \text { Adj. P-value }^{\mathrm{c}} & 0.766 & 0.940 & 0.650 & 0.585 & 0.541 & 0.946 & 0.511\end{array}$

\section{Paternal Atopy}

$\begin{array}{lrrrrrrr}\text { Yes }(\mathrm{n}=10) & 69.8 & 19.9 & 1.7 & 1.4 & 195 & 3.3 & 1090 \\ \text { No }(\mathrm{n}=18) & 92.7 & 26.5 & 3.5 & 2.4 & 291 & 3.6 & 1123 \\ \text { P-value } & 0.496 & 0.475 & 0.286 & 0.160 & 0.095 & 0.912 & 0.846 \\ \text { Adj. P-value }^{\mathrm{c}} & 0.634 & 0.720 & 0.306 & 0.197 & 0.377 & 0.668 & 0.797\end{array}$


478 Table 3. Influence of prenatal factors on percentages $\mathrm{CD} 4^{+}, \mathrm{CD}^{+} \mathrm{CD} 25^{+}$and $\mathrm{CD} 8^{+}$, respectively; and surface marker expressions in activated

479 cord blood $\mathrm{T}$ cells of healthy neonates.

\begin{tabular}{|c|c|c|c|c|c|c|c|c|c|c|c|c|c|c|c|c|c|}
\hline & $\begin{array}{r}\text { CD4 }^{+} \\
\text {Un- }\end{array}$ & $\mathrm{CD} \mathrm{CD}^{2} 5^{+}$ & CD71 & $\mathrm{CD}^{\mathrm{a}} \mathrm{9}^{\mathrm{a}}$ & CD25 & $\mathrm{CD}_{154^{\mathrm{a}}}$ & CD30 & CD278 & CD27 & $\begin{array}{r}\text { CD8 }^{+} \\
\text {Un-stimulated }\end{array}$ & CD71 & CD69 & CD25 & CD154 & $\mathrm{CD}^{\mathrm{a}} \mathrm{a}^{\mathrm{a}}$ & CD278 & CD27 \\
\hline & $\begin{array}{r}\text { stimulated } \\
(\%)\end{array}$ & (\%) & (MFI) & (MFI) & (MFI) & (MFI) & (MFI) & (MFI) & (MFI) & (\%) & (MFI) & (MFI) & (MFI) & (MFI) & (MFI) & (MFI) & (MFI) \\
\hline \multicolumn{18}{|l|}{ Sex } \\
\hline Male $(n=17)$ & 68.3 & 8.6 & 12297 & 10216 & 33935 & 1834 & 255 & 25712 & 36424 & 27.5 & 13295 & 3812 & 51571 & 766 & 100 & 15263 & 52694 \\
\hline Female $(n=11)$ & 73.9 & 8.1 & 12419 & 10443 & 36209 & 1883 & 237 & 27646 & 39755 & 21.5 & 13114 & 4159 & 57727 & 792 & 133 & 17536 & 56009 \\
\hline P-value & 0.063 & 0.594 & 0.894 & 0.817 & 0.227 & 1.000 & 0.670 & 0.382 & 0.134 & 0.048 & 0.881 & 0.445 & 0.041 & 0.881 & 0.926 & 0.204 & 0.213 \\
\hline Adj. P-value ${ }^{c}$ & 0.225 & 0.958 & 0.858 & 0.998 & 0.064 & 0.961 & 0.871 & 0.289 & 0.256 & 0.199 & 0.819 & 0.457 & 0.054 & 0.536 & 0.489 & 0.269 & 0.214 \\
\hline \multicolumn{18}{|l|}{ Parity } \\
\hline Primi $(n=14)$ & 69.8 & 7.7 & 12505 & 9517 & 31864 & 1896 & 233 & 25143 & 38029 & 25.6 & 13463 & 3628 & 52057 & 814 & 105 & 15334 & 54293 \\
\hline Multi $(n=14)$ & 71.1 & 9.2 & 12185 & 11093 & 37793 & 1809 & 263 & 27800 & 37436 & 24.7 & 12983 & 4268 & 55921 & 738 & 122 & 16979 & 53700 \\
\hline P-value & 0.660 & 0.113 & 0.723 & 0.210 & $0.0003^{\mathrm{d}}$ & 0.701 & 0.470 & 0.215 & 0.789 & 0.772 & 0.693 & 0.144 & 0.200 & 0.650 & 0.603 & 0.350 & 0.822 \\
\hline Adj. P-value ${ }^{c}$ & 0.301 & 0.275 & 0.880 & 0.201 & 0.0005 & 0.716 & 0.682 & 0.297 & 0.837 & 0.374 & 0.902 & 0.179 & 0.138 & 0.942 & 0.516 & 0.337 & 0.911 \\
\hline \multicolumn{18}{|l|}{ Maternal Atopy } \\
\hline Yes $(n=18)$ & 68.6 & 9.1 & 11775 & 10320 & 35317 & 1839 & 265 & 16121 & 53478 & 27.1 & 12790 & 4021 & 53456 & 672 & 108 & 16121 & 53478 \\
\hline No $(n=10)$ & 74.0 & 7.3 & 13371 & 10278 & 33950 & 1878 & 218 & 16220 & 54930 & 21.6 & 14005.7 & 3816 & 54950 & 963 & 123 & 16220 & 54930 \\
\hline P-value & 0.078 & 0.074 & 0.081 & 0.981 & 0.480 & 0.944 & 0.272 & 0.540 & 0.090 & 0.078 & 0.337 & 0.660 & 0.640 & 0.088 & 0.944 & 0.957 & 0.597 \\
\hline Adj. P-value ${ }^{c}$ & 0.106 & 0.215 & 0.438 & 0.490 & 0.610 & 0.515 & 0.629 & 0.611 & 0.507 & 0.081 & 0.849 & 0.850 & 0.886 & 0.052 & 0.504 & 0.754 & 0.684 \\
\hline \multicolumn{18}{|l|}{ Paternal Atopy } \\
\hline Yes $(n=10)$ & 70.8 & 8.0 & 13568 & 9691 & 34540 & 1721 & 224 & 25800 & 39730 & 25.4 & 14486 & 3638 & 54150 & 780 & 101 & 15280 & 55530 \\
\hline No $(n=18)$ & 70.3 & 8.7 & 11665 & 10646 & 34989 & 1926 & 262 & 26844 & 36622 & 25.0 & 12523 & 4120 & 53900 & 774 & 120 & 16643 & 53144 \\
\hline P-value & 0.862 & 0.505 & 0.035 & 0.555 & 0.817 & 0.724 & 0.384 & 0.645 & 0.172 & 0.921 & 0.115 & 0.296 & 0.938 & 0.975 & 0.555 & 0.460 & 0.383 \\
\hline Adj. P-value ${ }^{c}$ & 0.494 & 0.758 & 0.200 & 0.408 & 0.585 & 0.236 & 0.721 & 0.965 & 0.441 & 0.306 & 0.263 & 0.423 & 0.870 & 0.262 & 0.449 & 0.500 & 0.362 \\
\hline
\end{tabular}

$480 \quad{ }^{a} \mathrm{P}$-value (unadjusted) calculated using Unpaired Student's t-test, ${ }^{b} \mathrm{P}$-value (unadjusted) calculated using Mann-Whitney-Wilcoxon test, ${ }^{\mathrm{c}} \mathrm{P}$-values adjusted for possible

481 confounders (sex, parity, parental atopy) calculated using General Linear Models, ${ }^{\mathrm{d}} \mathrm{P}=0.004$ after Bonferroni correction 


\section{First-born Later-born}

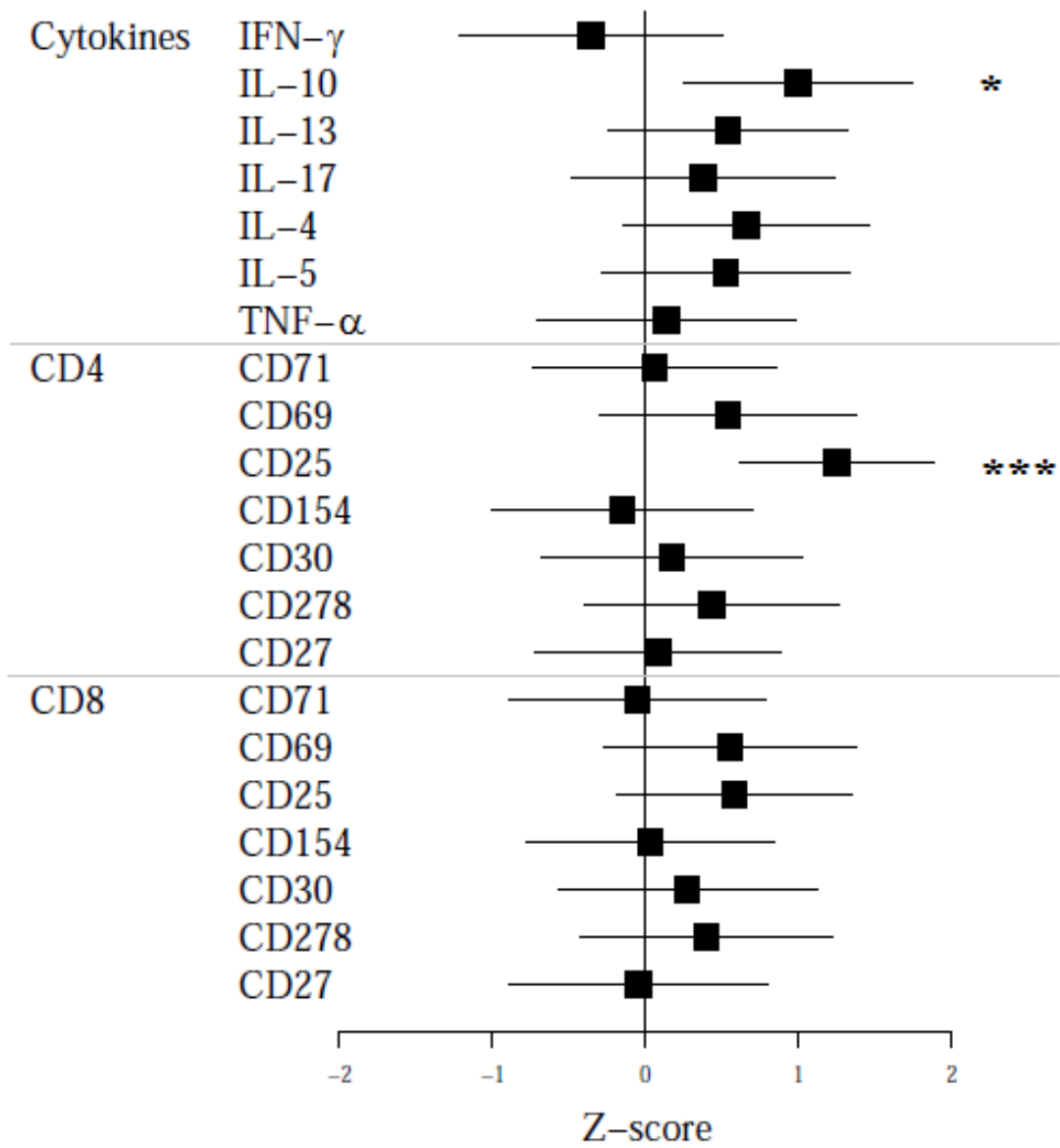

Figure 1. Differences in cytokine levels and surface marker expressions in activated cord blood T cells from healthy first-born infants versus later-born infants. Scaled, adjusted dependent variables (z-scores) expressed as differences between groups with corresponding 95\% confidence interval. Statistical analysis by GLM with sex, parity and parental atopy as covariates. *, $\mathrm{P}<0.05 ; * * *, \mathrm{P}<0.001$. CD154 (CD40L); CD278 (ICOS). 


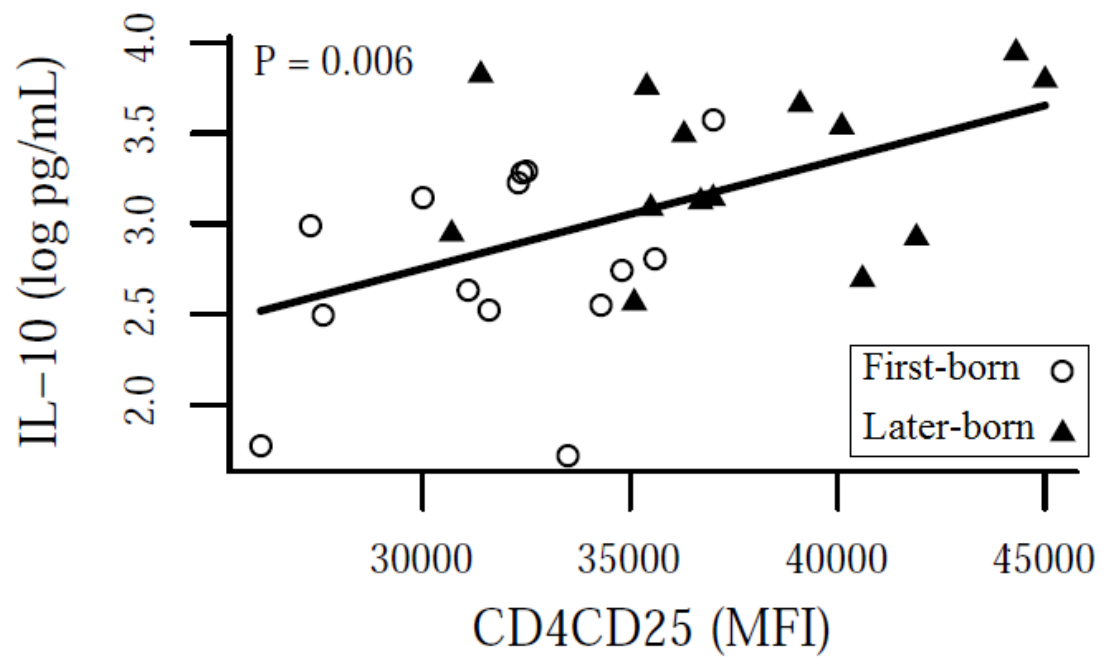

488

Figure 2. Correlation of CD25 expression on CD4 ${ }^{+} \mathrm{T}$ cells and secreted IL-10 in activated cord blood T cells of healthy first-born infants and later-born infants. IL-10 data are logtransformed. Pearson's correlation analysis was used to calculate statistics. 
A

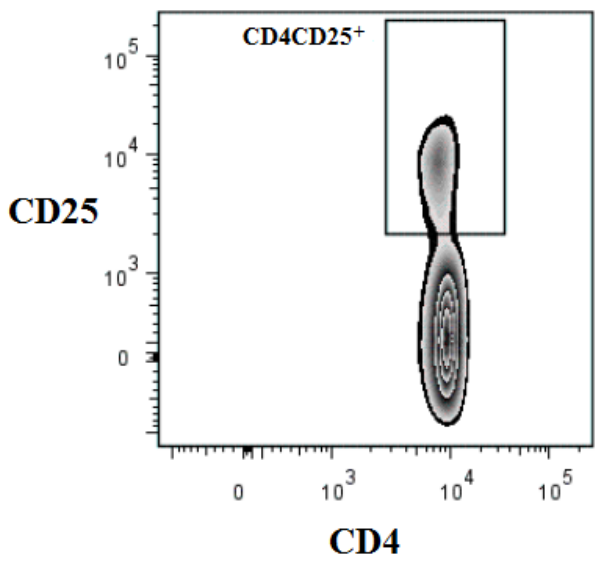

B

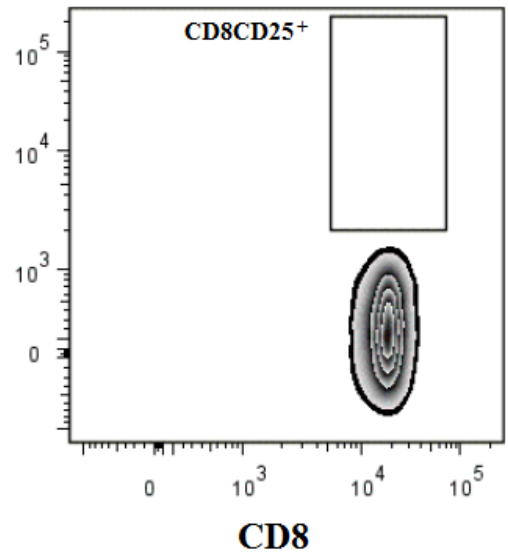

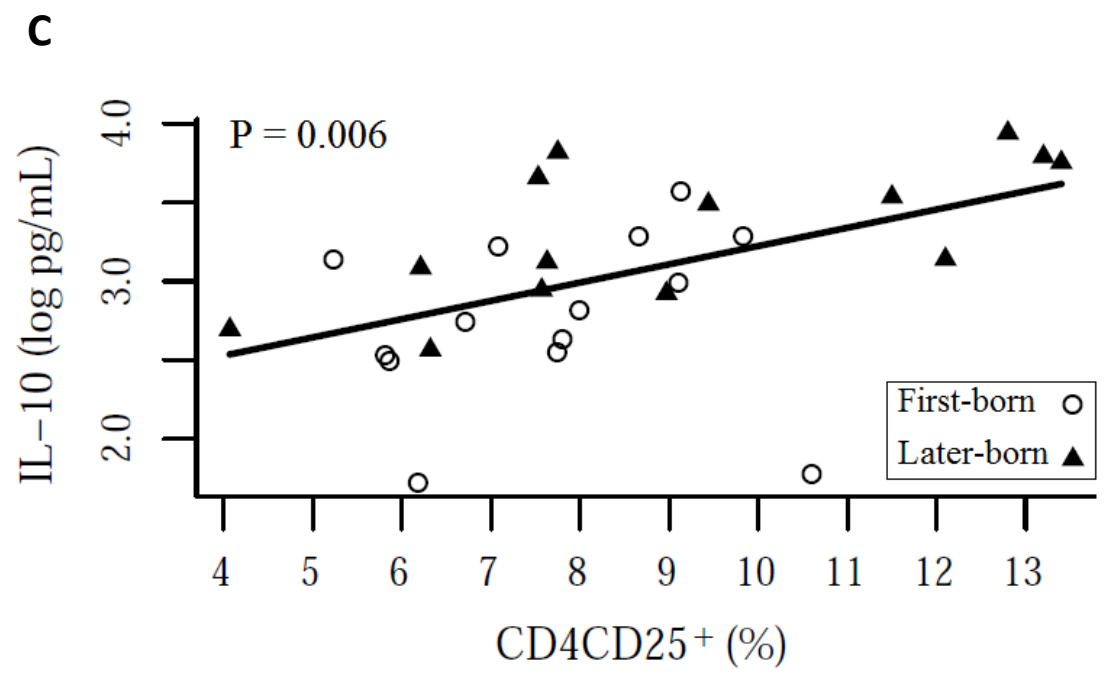

494

Figure 3. Presence of $\mathrm{CD} 4^{+} \mathrm{CD} 25^{+}$cells in un-stimulated cord blood T cells of healthy neonates. A. Gating of $\mathrm{CD}^{+} \mathrm{CD} 25^{+}$cells B. Gating of $\mathrm{CD} 8^{+} \mathrm{CD} 25^{+}$cells. A-B. Cord blood T cells were isolated as described in METHODS. One representative analysis out of 28 is shown. C. Correlation of the percentage of $\mathrm{CD} 4^{+} \mathrm{CD} 25^{+}$in un-stimulated cord blood $\mathrm{T}$ cells and secreted IL-10 in activated cord blood T cells of healthy first-born infants and later-born 
Kragh, 30

500 infants. IL-10 levels are log-transformed. Pearson's correlation analysis was used to 501 calculate statistics. 
A

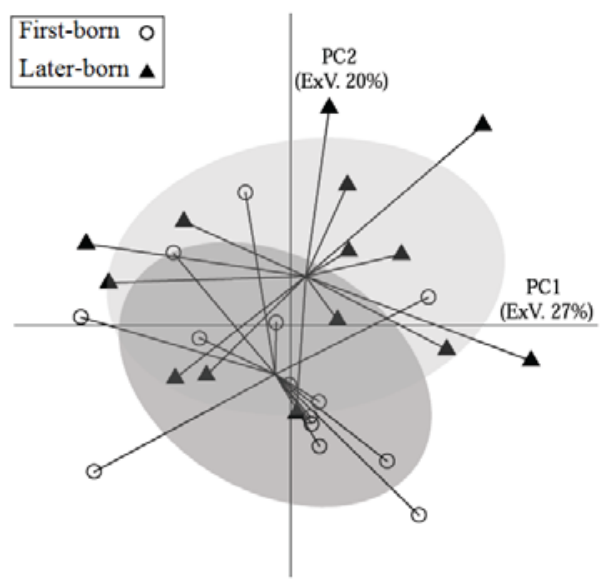

C

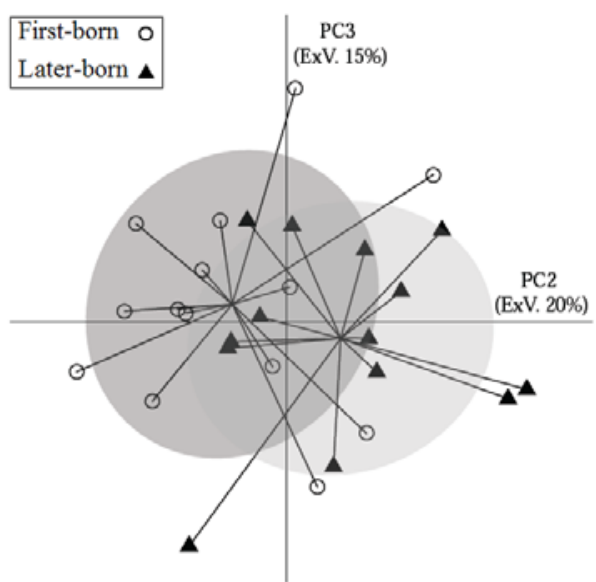

E

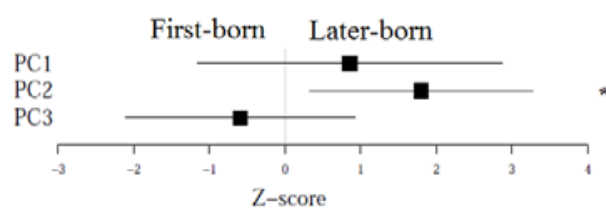

B

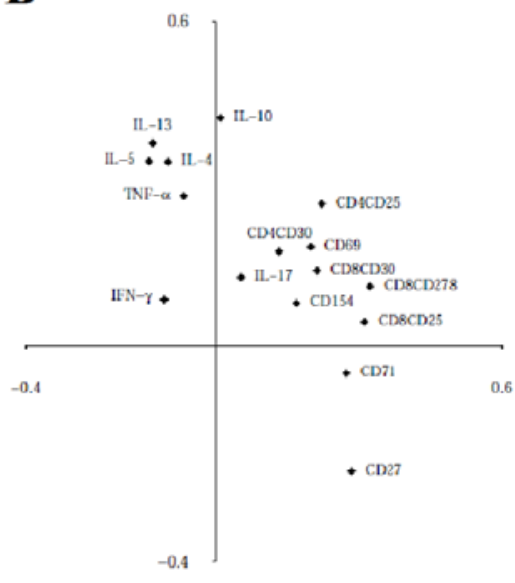

D

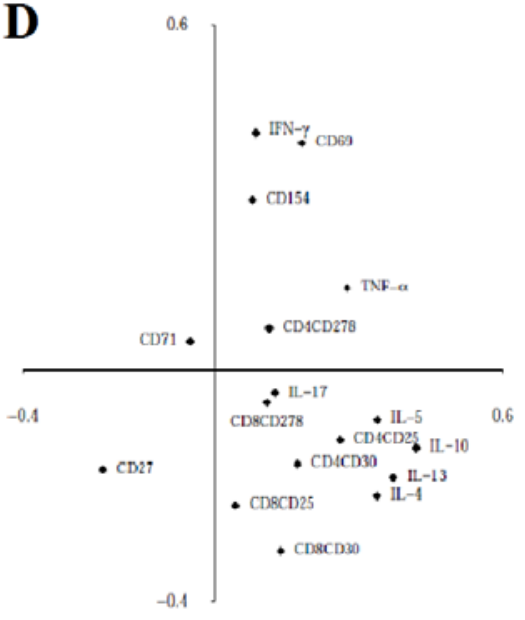

Figure 4. Principal component analysis of the combined immune profiles of activated cord blood T cells across first-born and later-born neonates. A, C. Score-plots grouped by birthorder. Principal components (PCs) are plotted using the ade4 package in R with each 
newborn represented by a symbol. The mean of each birth-order group is the center of the

507 ellipse and the colored area covers $67 \%$ of the samples belonging to this group. B, D. Loading-plots illustrate the systematic distribution of immune mediators determined by PCs. In cases where expression of a given activation marker were similar on CD4 and CD8 cells, only the marker name is indicated. E. Statistics on PCs divided by parity. Data are scaled, adjusted PCs (z-scores) based on a GLM with sex, parity and parental atopy as covariates;

512 and expressed as differences between groups with corresponding 95\% confidence interval. *, 513 $\mathrm{P}<0.05$. 
Kragh, 33

\section{SUPPLEMENTARY}

515

516

Table S1. Data on sex of baby; maternal and paternal atopy by parity status

\begin{tabular}{llcc}
\hline Parity & Sex & Maternal atopy & Paternal atopy \\
\hline Primi $(\mathrm{n}=14)$ & 6 females & 1 & 3 \\
& 8 males & 6 & 3 \\
\multirow{3}{*}{ Multi $(\mathrm{n}=14)$} & 5 females & 4 & 1 \\
& 9 males & 7 & 3 \\
\hline
\end{tabular}

517 
Figure S1. Activation propensity of the neonatal T cell compartment.

To explore the activation propensity of isolated neonatal $\mathrm{CD}^{+}$and $\mathrm{CD}^{+} \mathrm{T}$ cells at birth, we profiled the polyclonal response to anti-CD3/CD28 using multicolor flow cytometry. Our profile included early activation markers CD69, CD71, CD25 (aIL2-R) as well as CD27, CD30, CD154 (CD40L) and CD278 (ICOS). Upon polyclonal stimulation, we measured a complete activation of both $\mathrm{CD} 4^{+}$and $\mathrm{CD} 8^{+} \mathrm{T}$ cells with $1.6-4000$ fold changes in surface marker expression level dependent on the marker. Data shows representative histograms of surface marker expression levels before and after polyclonal activation of cord blood CD4 ${ }^{+}$ and $\mathrm{CD}^{+} \mathrm{T}$ cells for $24 \mathrm{~h}$.

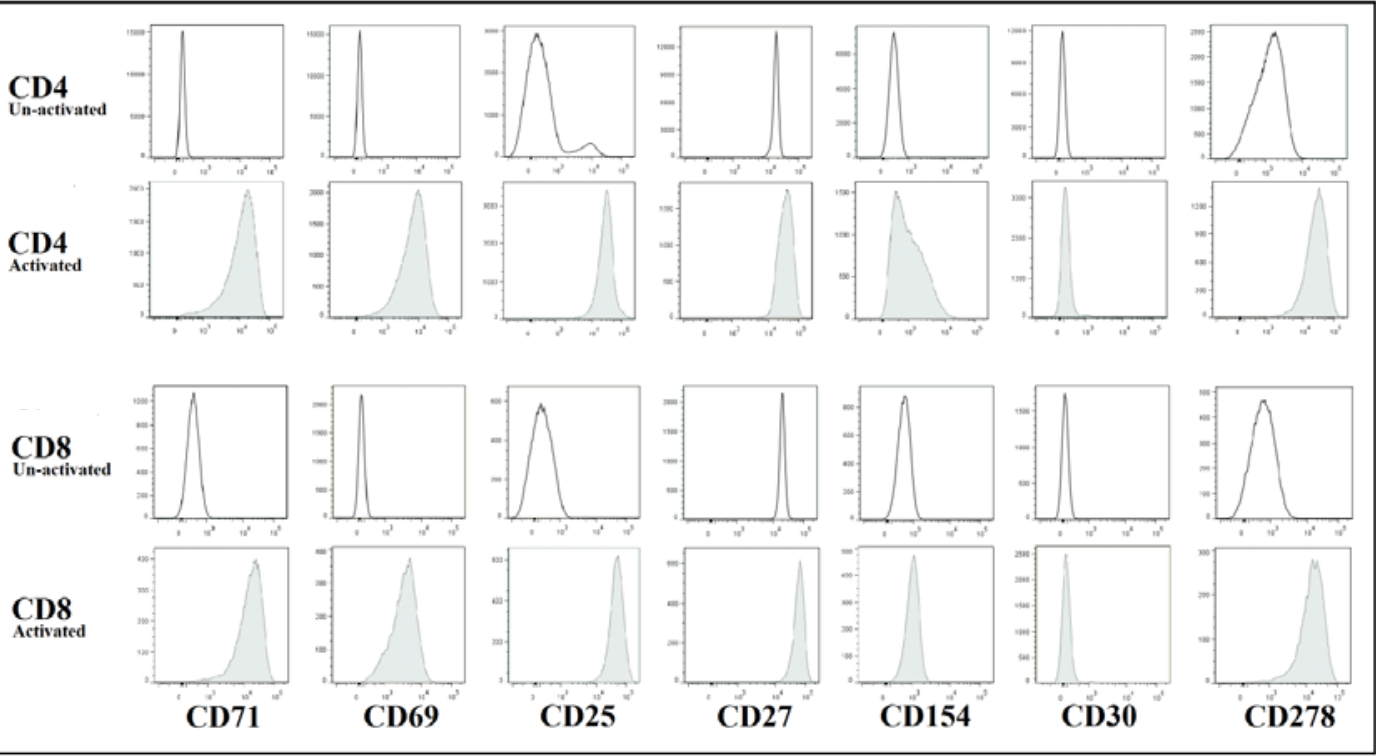


Figure S2. Correlation matrix of surface marker expression levels in activated cord blood

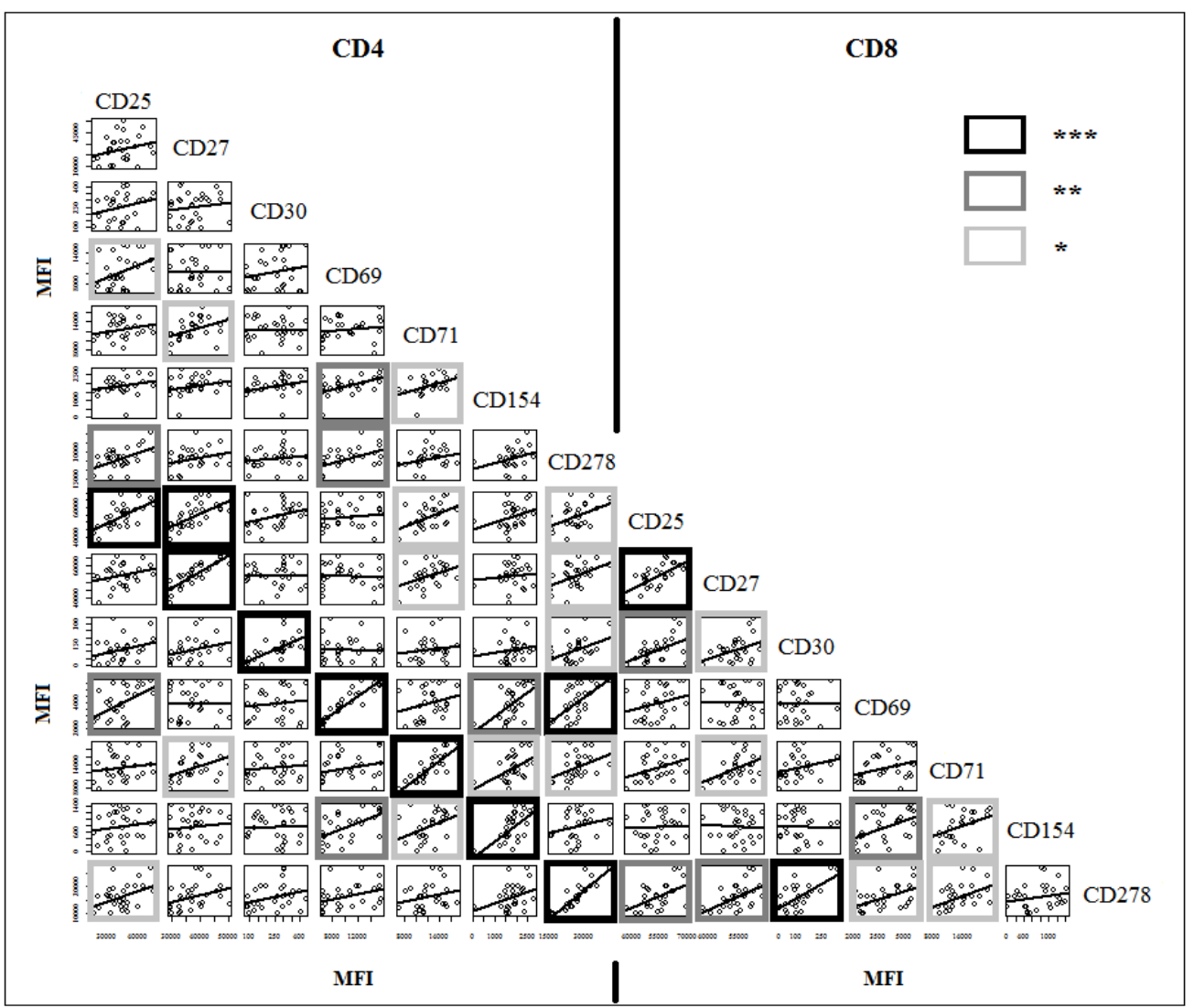




\section{Figure S3. Relatedness of activation markers and effector cytokines expressed in} activated cord blood $\mathbf{T}$ cells. Data show correlation matrix of cytokine and CD4+ surface marker expression levels in activated cord blood T cells of healthy neonates. Shown are regression lines and Pearson correlation statistics: *, $\mathrm{P}<0.05, * *, \mathrm{P}<0.01$; *** $\mathrm{P}<0.001$.

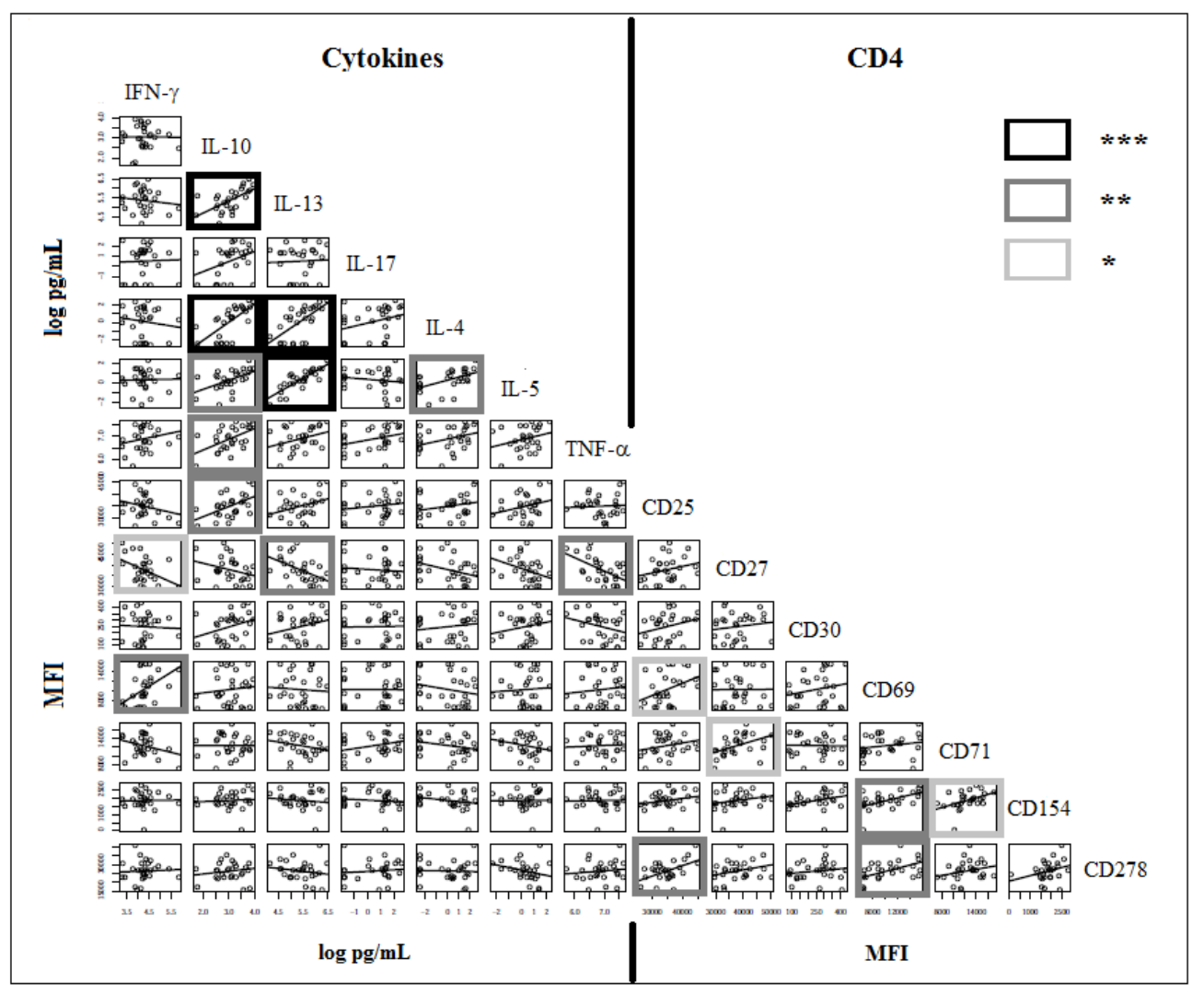


Figure S4. Correlation matrix of cytokine and $\mathrm{CD8}^{+}$surface marker expression levels

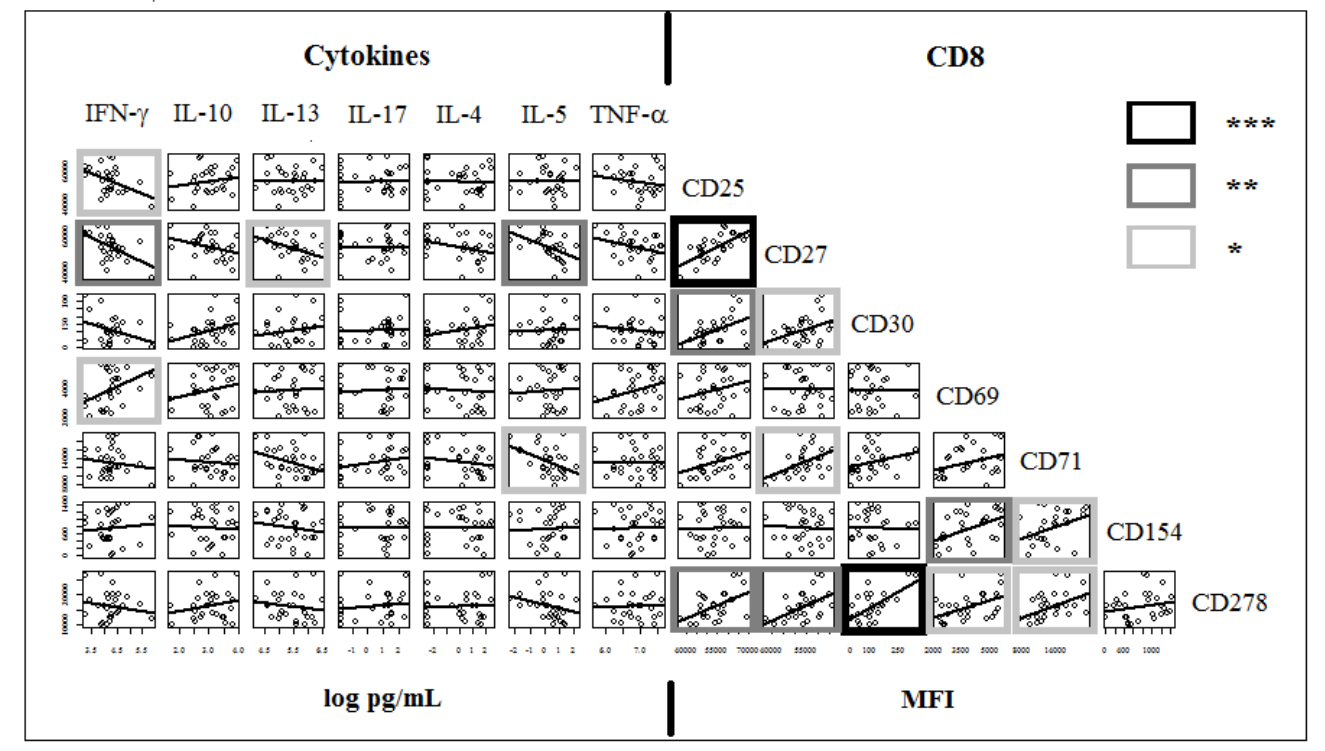

